\title{
THE ENTREPRENEURIAL PROCESS OF DISCOVERY IN REGIONAL DEVELOPMENT MANAGEMENT
}

\author{
Agata WARMIŃSKA \\ Rzeszow University of Technology, Faculty of Management; agataw@prz.edu.pl, \\ ORCID: 0000-0002-3283-4881
}

Purpose: The goal of the article was to try to reflect on the entrepreneurial process of discovery and its influence on sustainable regional development.

Design/methodology/approach: In the article, a method of literature review was used.

Findings: The article presents the theoretical analysis of the concept of smart specialisation and the entrepreneurial discovery process. The initiatives supporting the entrepreneurial discovery process were reviewed. Views were presented on the impact of the concept of smart specialisation on regional management.

Keywords: management, regional development, entrepreneurial process of discovery.

Category of the paper: Viewpoint, literature review.

\section{Introduction}

In economic sciences, the issue of regional development constitutes an important subject of research. The modern development models constitute the consequence of three phenomena: globalisation, competition and innovation. In a globalised economy, knowledge, entrepreneurship and innovativeness become increasingly important. This rule also applies to regions. An innovative region with social capital will react to the changes taking place in its environment more rapidly, or it will cause these changes (Gierczycka-Bednarek, 2009, p. 80). Together with the change of the external conditions, the approach to region management changes. The ability of regions to constantly produce and the skill to adapt new technologies, organisational solutions and knowledge influences development. An increase in competitiveness, the creation of a favourable climate for establishing and developing firms, as well as an increase in the readiness of enterprises to carry out innovative activities is noticeable in regions to which innovativeness constitutes a priority in terms of development policy (Tuziak, 2017, p. 112). 
The changes taking place on a global level result in the need for changes in the approach to regional development, which is a complex process, depending on many factors. The notion of regional development is understood as a constant process of an increase in the economic potential of regions, systematic improvement in their competitiveness and various aspects of the standard and quality of living of inhabitants. The endogenous potential and the ability to obtain and absorb exogenous sources, which are used for regional development, determine the possibility of changing the existing industrial paths and developing and implementing new growth paths (Isaksen et al., 2018, pp. 221-238). The main characteristic of regional development is economic growth resulting in social development (Przygodzki, 2007, p. 43). Economic development is very frequently understood as quantitative growth. However, it should be remembered that growth is an essential condition for development to take place, but growth alone is not enough (Trojak, 2013, p. 19). Increasing the competitiveness of the world market constitutes a challenge for countries, regions and enterprises that operate in their area. A region plays a special role in the process of knowledge and innovation creation (Nowakowska, 2009). The modern concepts of regional development underline the importance of the endogenous factors, which ensure long-term development (Sobol, 2017, p. 73). The basis for social and economic development is innovative solutions of a technological, economic and ecological nature. In 2010, the European Commission presented a new strategic concept of development - Europe 2020: A strategy for smart, sustainable and inclusive growth (Europe, 2010), and in this way, it set the direction and the policy of the development of the European Union for the years 2014-2020. The strategy constitutes a basic document specifying the premises of creation of the regional innovation strategy, in accordance with the concept of smart specialisations. The strategy based on smart specialisation constitutes a specified form of implementing innovation policy at a region level or country level. By definition, smart specialisation is not a top-bottom strategy of enforcing particular specialisations on regions (Estensoro et al., 2016, pp. 1319-1335). This concept is aimed at an increase in the competitiveness of regions and their more rapid development on the basis of their endogenous potential and combining the research sphere with economic development of particular areas involving the engagement of various stakeholders (firms, private persons and organisations with adequate knowledge) (Przewodnik, 2012, pp. 13-17). The idea of smart specialisation focuses on regional development, which is a result of stimulating diversification in a given area perceived as developmental (Boschma, 2014). The main method of identification of smart specialisations is the entrepreneurial process of discovery.

The goal of the article was to try to reflect upon the entrepreneurial process of discovery and its influence on sustainable regional development. In the article, a method of literature review was used. 


\section{Regional Development Management}

Regional development is a highly complex and multidimensional process, the effects of which can be noticed only after a long period of time from the commencement of development actions.

Literature on the subject has not formed a clearly defined concept of regional development. It is perceived by different authors (Strzelecki, 2008, p. 79) as:

- a process of all quantitative and qualitative changes occurring in a region,

- a social process aimed at the improvement of the standard and quality of life of a region's community,

- technical and technological progress aimed at the rational use of a region's factors and resources,

- a process leading to economic development.

Regional development is most frequently defined as changes occurring in a region. In the case of positive changes, we talk about progressive development. If changes are of a negative nature, they result in negative development.

Regional development factors comprise these elements and characteristics of regions and their surroundings and events occurring therein which cause the transformation of the region from a simple form to a more complex and better structure (Churski, 2008, p. 33).

One of the purposes of regional development is to improve the quality of life of its residents, understood as the ability to satisfy the needs of current and future generations (Kronenberg, Bergier, 2010, p. 24).

Regional policy is based on the concept of sustainable development. The region fully develops if changes occur simultaneously in the economic, social, technical, technological and environmental areas. The assumptions of sustainable development focus on the achievement of three purposes (Skowroński, 2006, p. 51):

- environmental purpose - consisting in the prevention of environmental degradation and the elimination of threats to the environment;

- economic purpose - expressed in the satisfaction of people's essential material needs with the use of technique and technology that do not have a negative impact on the environment;

- social purpose - which assumes securing the subsistence minimum, health protection, people's spiritual dimension development, safety and education.

The development capacities of individual regions depend on their internal capacities and endogenous potential. Today, the pace and shape of development processes in a region are greatly influenced by new technologies and innovations. 
Isaksen et al. describe five regional industrial development paths (Isaksen et al., 2018, pp. 221-238):

- path extension - the development of existing, technologically founded industry branches by incremental innovation;

- path upgrading - the change of the established direction due to the implementation of technological or organisational innovation;

- path branching - may occur when a new sector is developed out of the existing sectors and on the basis of regional capabilities;

- path importation - the creation of established sectors in a region where they have not existed before;

- path creation - the creation and development of new industrial sectors on the basis of innovation.

The process of choosing the direction of regional development on the basis of the change of industrial paths or introduction of new sectors will always have a different course, as it depends on the regional capabilities to determine and implement the innovative development strategy.

The regional development process is highly dominated by management. For many years, the management of regional development in Poland has been rather ineffective. A new approach concentrated on strengthening the economy on the knowledge basis, and making efforts to effectively use the possessed resources and improving innovativeness has created new possibilities for regional development. Only regions with the capacity to create and continuously develop innovative eco-systems and internal learning mechanisms may maintain a permanent competitive advantage (Szewczuk, 2011, p. 94).

Regional development management concerns different operations and areas. The management process includes the following functions: planning and making decisions, organising, leading and controlling. The basis of operations undertaken in the process of regional development management constitutes planning, especially planning in the context of long-term (strategic) development. The special role of planning is connected with the uneven development of regions and the occurrence of economic and social imbalances. In order to eliminate current problems, it is necessary to undertake actions exploiting the existing development factors. Another element of regional development management is the establishment of directions of regional development and the coordination of actions aimed at the implementation of adopted purposes.

Effective regional development management primarily depends on the identification of opportunities, possibilities and possible threats to the development, as well as on the creation of conditions allowing for the exploitation of opportunities and the elimination of threats. An essential element of regional development management is also strategic orientation leading to the determination of long-term development directions allowing for the exploitation of existing opportunities and development factors (Szewczuk, 2011, p. 97). 
Regional development management is possible only due to a properly developed and implemented strategy. It is of high importance in modern regional development to ensure its continuous character.

Pursuant to the recommendations of the European Commission, regional innovation strategies, constituting the complementation of the development strategy, are created on the basis of the concept of smart specialisation.

\section{Smart specialisation - basic premises}

The concept of development based on smart specialisation was created in 2009, when “The Knowledge for Growth" experts' group, appointed by the Research Committee, developed the basic premises of intelligent specialisation. According to experts, regions, especially developing regions, should focus on gaining a competitive advantage related to specified domains, technologies and subsystems (Forey, 2014, p. 492). Such an approach gained greater importance, becoming the basis of the policy of regional development and the cohesion policy of the European Union in the 2014-2020 programming period. The European Commission provided a legal framework of the concept of smart specialisation, and the documents where the method of selecting smart specialisations for regions were indicated. The premises of the concept of smart specialisation are related to, among others, previously known theories (Słodowa-Hełpa, 2013, pp. 90-91):

- the theory of a basic product - the theory indicates that specialisation in terms of the group of the most competitive goods enables achieving regional development;

- the theory of flexible production - according to the theory, the development is based on specialised small and medium enterprises;

- clusters theory of M. Porter - in accordance with the theory, the bases of development are cooperation and geographical proximity;

- growth poles theory of F. Perroux;

- economic base theory of H. Hoyt;

- other growth theories.

The main assumption of the concept of smart specialisation is separating the unique strengths and opportunities characteristic for a particular country. The selection of a smart specialisation is aimed at the optimal use of the resources of a region by the best possible matching of the potential of science-education and economy (Kardas, 2011, p. 129). The implementation of smart specialisation strategies in the regions is not a single event but a continuous management process (McCann et al., 2016, pp.1407-1427). 
The presented approach also underlines the importance of a strategic cross-frontier and interregional cooperation. This kind of cooperation contributes to the increasing potential and diversity of a region. Application of the smart specialisation approach requires taking into consideration the differences between regions and the area of a particular region in economic and institutional conditions. The basis of the concept of smart specialisations is the endogenous context and the concentration on the specific resources and abilities of a particular region. The endogenous development potential was specified as a sector or a group of sectors of economy that are already specialised and that have gained a certain competitive advantage at a national level. Moreover, they should meet the following conditions: inveteracy in the region's economy, similarity in terms of technology and communication and cooperation in and between sectors. In literature, there were expressed opinions that the premises of innovation policy should be combined with the premises of the endogenous growth model, as the knowledge constituting the source of innovation is the result of the decisions made by enterprises and governments. Świadek and Tomaszewski underline that in the case of weak Polish regions at a low level of economic development, the endogenous theory of growth may face barriers as a result of specific types of inequalities (Świadek, Tomaszewski, 2012, pp. 87-88). Innovation at enterprises in periphery regions is limited by the inability to access local knowledge (Grillitsch et al., 2015, pp. 299-321).

The concept of a smart specialisation is based on four principles (Nazarko, 2014, p. 250):

- the focus on the specialisations that are complementary to the resources of a particular region, making it possible to gain a comparative advantages (avoiding duplication of specialisations), selection of sectors capable of establishing "critical mass";

- matching R\&D\&I to the needs of business;

- the development of clusters and the creation of cross-sectoral cooperation platforms;

- management of an innovation system based on public-private partnership.

The focus on the listed premises is to lead to the creation of economies of scale and the development of distinctive specialisations (Miłek, 2013, p. 192).

In the process of selection of smart specialisation, the main role should be played by all the stakeholders in the world of entrepreneurship (inter alia firms, universities, public research institutes), as thanks to their knowledge and commitment, it is possible to distinguish the priority areas, in the case of which the probability of growth is high. It is virtually impossible and too expensive to involve all entrepreneurs in the selection of smart specialisation. Therefore, it is necessary to use an adequate method of selecting business stakeholders, e.g. by taking into account the optimisation of resource allocation (Martínez-López et al., 2015, pp. 1-14). One of the premises of the smart specialisation of regions is a proper relation between science, the public sphere, education and business (Brzóska, 2016, pp. 9-26). The "smart specialisation" concept highlights the important role played by universities, as they are the leading regional institutions that are involved in the creation of sustainable development, as well as in the transfer of innovation and technology in a given region (Prause, 2014, 
pp. 3-19). It is important to, in the process of selection of smart specialisations, avoid imitating other regions and supporting the previously identified areas. Forey indicates three levels of creation of the economy based on the smart specialisation concept: experimenting and discovery; evaluation of results and creating the line of development; support of the most promising projects. The author also underlines that not all regions must implement their development policy in the same way (Forey, 2012, pp. 279-281). The selection of a proper, key smart specialisation is possible only thanks to sound knowledge of the local context. The selection of this development concept is to make possible the focusing of public intervention on the activities and projects which contribute to the specialisation of a particular region.

A smart specialisation enables the shaping and development of the current and the future position of a region in a knowledge-based economy (Szostak, 2015, p. 213). The choice of smart specialisation should include the issues of diversification and specialisation. If differences specific to a given region are identified, it will help to recognise future competitive advantages in a reasonable manner. At the same time, it will prevent any future random R\&D projects that are unrelated to the development of the region (Foray et al., 2018a). The effect of implementation of a smart specialisation is not unification, but an increase in diversity. Regions may select a few priorities which may result in switching the current sector for a new one, diversification, modernisation of the existing sector or creation of a new domain (Przewodnik, 2012, pp. 16-17).

In addition to the undeniable advantages and benefits of implementation of the concept of smart specialisations, in literature there were also indicated the potential threats, e.g. favouring $\mathrm{R} \& \mathrm{D}$ projects and providing areas of relatively low productivity with support, which may result in increased disparities between regions (Dziedzic, 2018, p. 120).

\section{Entrepreneurial discovery process (EDP)}

The entrepreneurial discovery process is extensively described by many authors. Entrepreneurial discovery may be defined as a learning process due to which a given region gradually discovers priorities on which it should focus in the area of innovation research and development (del Castillo Hermosa, 2015, p. 9). Entrepreneurial discovery does not correspond to a specific sector model, but to the combination of creative methods of using opportunities resulting from the possession of endogenous territorial assets. The described process is also called self-discovery. It consists in the increase in knowledge of entrepreneurs of the fact that they may locally, at lower costs, manufacture the same goods as in other regions, but they must take into account differences and diversified operational conditions. The entrepreneurial 
discovery process allows entrepreneurs to combine current knowledge and experience in a new way (Alvarez et al., 2007, pp. 11-26).

The key role in the development and increase in innovativeness is played by the change in the existing methods of enterprises' operations, consisting in the creation of a competitive advantage and the inclusion into the process of entrepreneurial discovery of entities which have not participated in it so far. Entrepreneurial discovery concerns all stakeholders from the world of entrepreneurship that can precisely indicate these $R \& D$ and innovation areas in which the region has the greatest opportunities for success, taking into account current and future possibilities. It is assumed in entrepreneurial discovery that entrepreneurs know best what constitutes the stronger point of their activities. Entrepreneurs not only know the technologies applied in their sector, but they can also combine scientific and technological knowledge with knowledge of the market they operate on, their competitors, as well as the resources necessary to set up a new business. Due to such skills, they are able to notice new opportunities and possibilities in existing and emerging sectors. This kind of knowledge and skill is used in the process of smart specialisation identification.

The entrepreneurial discovery process proceeds faster in developed regions, where entrepreneurs constitute an essential factor of economic growth. In the conditions of increased competition, entrepreneurs form a group of innovators and make decisions under conditions of uncertainty and dispersed knowledge. They also discover new profitable opportunities and transfer market knowledge into practical use. In regions with a small capacity of entrepreneurship, it is necessary to activate knowledge through supporting the cooperation of universities or official institutes with local enterprises.

Due to the entrepreneurial discovery process, both regions and entrepreneurs discover new development possibilities based on the implementation of business and social and environmental innovations through the use of endogenous regional resources (Markula, Kune, 2015).

This process is based on strategic cooperation between different stakeholders, aimed at overcoming development obstacles and exploiting existing opportunities (Mieszkowski, Kardas, 2015, pp. 357-384). In view of the increased complexity and diversity of modern-day knowledge, it is necessary to integrate and cooperate in the process of creating regional and supra-regional knowledge. The regional development policy is based on various actors, e.g. companies, universities, $R \& D$ organisations, etc. Its goal is to strengthen the innovation potential, as well as to increase the effectiveness of individual stakeholders (Asheim et al., 2011, pp. 893-904).

Pursuant to the concept of smart specialisations, the entrepreneurial discovery process performed so far at the micro level should be transferred to the macro level with a focus on the performance of a selected group of priorities, and not single processes and initiatives, which will result in systematic regional development (del Castillo Hermosa, 2015, p. 10). Regions with similar factors of production may specialise in different types of activities. 
Such a possibility is ensured by adjusting the same technology to local conditions. The entrepreneurial discovery process has been carried out in Poland both at the national and regional level (Wiktorska-Świecka, Klimowicz, Michalewska-Pawlak, 2017, p. 200).

Entrepreneurial discovery is a continuous process aimed at the "identification of areas with potential for establishing critical mass on the basis of local (endogenous) resources" (Towards, 2015 , p. 12). The characteristic is an "ongoing dialogue" of participants of the regional innovation system at all stages of this process (Dziedzic, 2018, p. 127). The stakeholders that participate in entrepreneurial discovery cannot take into account only the interests of the group they represent when they make a decision about the selection of regional smart specialisation (Hassink et al., 2019, pp. 2049-2065). Despite uniform assumptions, the entrepreneurial discovery process has proceeded differently in each region. For the purposes of selecting the best functioning and the most effective solutions, cooperation between regions consisting in the exchange of good practices is necessary.

During the selection of priorities in the entrepreneurial discovery process, regions should avoid the mistake of following the operations implemented by other regions. Solutions that work in developed regions may not always be appropriate for small regions. The selection of priorities not adjusted to the potential of a given region will have a negative impact on the possibility to single out.

Entrepreneurial discovery is a process driving innovations, supporting the transformation of demand into supply and knowledge into values. Knowledge from different areas is used to create the vision of new economic opportunities for a region in the process of entrepreneurial discovery (Piirainen et al., 2017, pp. 289-300). The effects of entrepreneurial discovery include creative solutions to problems, resulting from combining available resources and new business partners, undertaking risks, experimenting, searching for new ideas within the value chain or joining new value chains (Panorama, 2012, p. 9).

In the opinion of Markkula and Kune (Markkula, and Kune, 2015, p. 6), in order to ensure the correct development of an innovation eco-system, it is necessary to create such conditions in which various entities may cooperate with one another, strengthening their own potential and contributing to the development of the entire eco-system. However, this pertains not only to innovation within the advanced technology sector, but also to the creation of complementary innovation in existing sectors (Foray, 2018b, pp. 817-832).

\section{Initiatives supporting the entrepreneurial discovery process}

The key point of the performance of the entrepreneurial discovery process is the active participation of different stakeholders (theoreticians and practitioners). In order to overcome barriers to development, the government and the private sector should continuously undertake 
cooperation. Partnership between the public and private sector is necessary to obtain knowledge about probable obstacles on the development path and to identify possible remedies (McCann et al., 2011). This kind of cooperation facilitates the identification of dispersed knowledge and individual experience (Dziedzic, 2016, p. 111). The effects of the entrepreneurial discovery process (EDP) depend to a great extent on the correct selection of stakeholders and the maintenance of their engagement in the entire process.

A characteristic of the entrepreneurial discovery process is "participation". It is commonly believed that the performance of the assumptions of the regional development strategy cannot be based solely on the regional authorities. In order to achieve the goal, the engagement and cooperation of state and local government authorities, science and business sectors, as well as business environment institutions, are necessary. Each stakeholder plays an important role in the process of selecting smart specialisations. An increase in the engagement of economic entities, which is possible in developed regions, is of key importance. In less developed regions, public authorities should increase their commitment. The role of state and local government authorities is to grant support that will contribute to economic and innovation development in identified smart specialisations and create knowledge-sharing mechanisms strengthening entrepreneurial discovery. Foray et al. (2009, p. 15) indicate that the role of regional authorities should consist in: encouraging entrepreneurs to be more engaged in the process, ensuring support addressed to entrepreneurs of significant competitive potential and with great power of influence, support for new activities, as well as the flow of information and conditions for cooperation.

The entrepreneurial discovery process is of a continuous nature. In order to initiate, facilitate and maintain mutual cooperation between different groups of stakeholders, it is necessary to undertake initiatives supporting mutual relationships.

One of the initiatives aimed at initiating cooperation between stakeholders has been the creation of platforms for the exchange of information, good practices and opinions on innovativeness, which function not only at a regional level. As an example, it is worth mentioning innovativeness forums, which are meetings devoted to innovativeness comprising, for instance, conferences with thematic sessions and brokerage meetings creating relationships between stakeholders from the science and business sectors. Another proposal is the creation of advisory and decision-making teams which would gather representatives of entrepreneurs, universities and research \& development units, local and state government authorities, as well as people interested in issues of innovation development in the region.

An important initiative undertaken by regional authorities (e.g. in France) in order to promote key industrial sectors is the negotiation of partnership agreements with industry leaders being strategic and business partners. Due to the negotiations conducted, it is possible to identify new activities of high development potential and to determine common purposes. Partnership agreements constitute the basis for regional cooperation between different stakeholders, as well as generate new projects implemented within the network of relationships 
and, due to the engagement of entrepreneurs, the sense of being anchored in the local environment.

A good example (e.g. in Germany, France and Sweden) of the regional system of supporting innovativeness in selected areas of business operations, including active engagement of entities from the public, private and research sectors, is the support for a cluster policy based on "labelling" recognisable and highly specialised clusters, as well as clusters of great innovative potential and appropriate critical mass. This kind of activity is aimed at strengthening the capacity of clusters and the entities associated therein to implement innovations.

\section{Summary}

Globalisation results in a change of the paradigm of regional development. Global processes occurring nowadays in the economy strengthen regional identity and the sense of belonging to the same economic, social and cultural region.

The development of a region and its capacity to achieve a permanent competitive advantage depend on the local development potential and development needs. Intangible resources (knowledge and innovativeness) are becoming increasingly important.

At present, in region management, an integrated approach based on region specialisation is applied. Smart specialisation is a new approach in regions towards the creation of a development strategy oriented at innovativeness and based on regional strengths and competitive advantages. The aim of regional development management based on this concept is the stimulation of smart growth by the selection of specialisations which can be developed in a given region. While selecting the specialisation, special attention is paid to regional resources, the partnership of stakeholders from the world of entrepreneurship and the possibility of effective use of public and European funds.

Smart economic growth may exclusively ensure the combination of smart specialisations with permanently balanced development.

The entrepreneurial discovery process allows for the creation of a development strategy based on the unique resources of a given region.

The main problem in the implementation of the smart specialisation concept may be the inappropriate selection of solutions which will be supported and, finally, prove to be ineffective, as well as support for solutions which, in the case of less developed regions, will cause their marginalisation.

Regional development management on the basis of the smart specialisation concept will not result in a complete reduction of development differences in individual regions, but will show less developed regions the possibility of how to use their endogenous resources for achieving comparative advantages in the longer term. 


\section{References}

1. Alvarez, S.A., and Barney, J.B. (2007). Discovery and creation: alternative theories of entrepreneurial action. Strategic Entrepreneurship Journal, 1(1-2), 11-26.

2. Asheim, B.T., Isaken, I., Nauwelaers, C., Tödtling, F. (eds.) (2003). Regional Innovation Policy for Small-Medium Enterprises. Cheltenham: Edward Elgar.

3. Boschma, R. (2014). Constructing regional advantage and smart specialisation: Comparison of two European policy concepts. Scienze Regionali.

4. Brzóska, J. (2016). Rola inteligentnych specjalizacji w projektowaniu i wdrażaniu regionalnej strategii innowacji województwa śląskiego. Nauki o Zarzadzaniu, 26(1), 9-26.

5. Churski, P. (2008). Czynniki rozwoju regionalnego i polityka regionalna w Polsce wokresie integracji z Unia Europejska. Poznań: Wydawnictwo UAM.

6. del Castillo Hermosa, J., Elorduy, J.P., and Eguía, B.B. (2015). Smart specialization and entrepreneurial discovery: Theory and reality. Revista Portuguesa de Estudos Regionais, 39, 5-22.

7. Dziedzic, S. (2018). Ekoinnowacje $w$ regionalnych strategiach innowacji. Istota, uwarunkowania, modelowanie. Rzeszów: Oficyna Wydawnicza Politechniki Rzeszowskiej.

8. Dziedzic, S., Woźniak, L., and Czerepiuk, P. (2016). Proces przedsiębiorczego odkrywania jako metoda strategicznego planowania i implementacji inteligentnych specjalizacji regionu. Prace Naukowe Uniwersytetu Ekonomicznego we Wroctawiu, 444, 107-118.

9. Estensoro, M., and Larrea, M. (2016). Overcoming policy making problems in smart specialization strategies: Engaging subregional governments. European Planning Studies, 24(7), 1319-1335.

10. Europa 2020. Strategia na rzecz inteligentnego i zrównoważonego rozwoju sprzyjającego właczeniu społecznemu, Komunikat Komisji KOM. Bruksela 3.03.2010. Source: https://ec.europa.eu/eu2020/pdf/1_PL_ACT_part1_v1.pdf, 14.10.2019.

11. Foray, D. (2009). Understanding "smart specialisation" The Questions of $R \& D$ Specialisation. Perspectives and policy implications. Luxembourg: Office for Oficial Publications of the European Communities.

12. Foray, D. (2012). Smart specialisation: from academic idea to political instrument, the suprising destiny of a concept and the difficulties involved in its implementation. In: E. Latoszek, I.E. Kotowska, A.Z. Nowak, and A. Stępniak (Eds.), European Integration Process in the New Regional and Global Settings. Warszawa: Wydawnictwo Naukowe Wydziału Zarządzania Uniwersytetu Warszawskiego.

13. Foray, D. (2014). From smart specialisation to smart specialisation policy. European Journal of Innovation Management, 17(4), 492-507. Source: http://dx.doi.org/10.1108/ EJIM-09-2014-0096, 14.10.2019. 
14. Foray, D. (2018b). Smart specialization strategies as a case of mission-oriented policy a case study on the emergence of new policy practices. Industrial and Corporate Change, 27(5), 817-832.

15. Foray, D., Morgan, K., and Radosevic, S. (2018a). The role of smart specialization in the EU research and innovation policy landscape. Brussels: European Commission. http://ec.europa.eu/regional_policy/sources/docgener/brochure/smart/role_smartspecialisat ion_ri. pdf, 13.2019.

16. Gierczycka-Bednarek, A. (2009). Globalizacja, innowacja i konkurencja w procesie rozwoju regionów unijnych. In: D. Kopycińska (Ed.), Ekonomiczne problemy funkcjonowania współczesnego świata. Szczecin: Katedra Mikroekonomii Uniwersytetu Szczecińskiego.

17. Grillitsch, M., and Nilsson, M. (2015). Innovation in peripheral regions: Do collaborations compensate for a lack of local knowledge spillovers? The Annals of Regional Science, 54(1), 299-321.

18. Hassink, R., and Gong, H. (2019). Six critical questions about smart specialization. European Planning Studies, 27(10), 2049-2065.

19. Hełpa-Słodowa, M. (2013). Inteligentna specjalizacja polskich regionów. Roczniki Nauk Spolecznych, 5(41), 87-120.

20. Inteligentna specjalizacja. Stymulator przyszłego rozwoju Europy. Panorama, 44, 8-12. http://ec.europa.eu/regional_policy/information/panorama/index_pl.cfm, 16.10.2019.

21. Isaksen, A., Tödtling, F., and Trippl, M. (2018). Innovation policies for regional structural change: Combining actor-based and system-based strategies. In New Avenues for Regional Innovation Systems-Theoretical Advances, Empirical Cases and Policy Lessons. Springer, Cham, 221-238.

22. Kardas, M. (2011). Inteligentna specjalizacja - (nowa) koncepcja polityki innowacyjnej. Optimum. Studia Ekonomiczne, 2(50), 121-136.

23. Kronenberg, J., and Bergier, T. (2010), Wyzwania zrównoważonego rozwoju w Polsce, Kraków: Fundacja Sendzimira.

24. Markkula, M., and Kune, H. (2015). Orchestrating an Entrepreneurial Discovery Process. Open Innovation 2.0 Yearbook 2015.

25. Martínez-López, D., and Palazuelos-Martínez, M. (2015). Breaking with the past in smart specialisation: A new model of selection of business stakeholders within the entrepreneurial process of discovery. Journal of the Knowledge Economy, 1-14.

26. McCann, P., and Ortega-Argilés, R. (2011). Smart specialisation, regional growth and applications to EU cohesion policy. IEB Working Paper, 14.

27. McCann, P., and Ortega-Argilés, R. (2016). The early experience of smart specialization implementation in EU cohesion policy. European Planning Studies, 24(8), 1407-1427. 
28. Mieszkowski, K., and Kardas, M. (2015). Facilitating an entrepreneurial discovery process for smart specialisation. The case of Poland. Journal of the Knowledge economy, 6(2), 357-384.

29. Miłek, D. (2013). Specjalizacje regionalne a Strategia Europa 2020. Zarzadzanie i Finanse - Journal of Management and Finance, 1(2), 189-199.

30. Nazarko, Ł. (2014). Inteligentne specjalizacje polskich regionów-przyczynek do ewaluacji. Przedsiębiorczość i Zarządzanie, XV(8), 1, 247-262.

31. Nowakowska, A. (2009). Regionalny kontekst procesów innowacji. In: A. Nowakowska (Ed.), Budowanie zdolności innowacyjnych regionów. Łódź: Wydawnictwo Uniwersytetu Łódzkiego.

32. Piirainen, K.A., Tanner, A.N., and Alkærsig, L. (2017). Regional foresight and dynamics of smart specialization: A typology of regional diversification patterns. Technological Forecasting and Social Change, 115, 289-300.

33. Prause, G. (2014). Smart specialization and EU eastern innovation cooperation: a conceptual approach. Baltic Journal of European Studies, 4(1), 3-19.

34. Przewodnik strategii badań i innowacji na rzecz inteligentnej specjalizacji (RIS3) (2012). Luksemburg: Urząd Publikacji Unii Europejskiej.

35. Przygodzki, Z. (2007). Region i klasyczne teorie jego rozwoju. In: J. Chądzyński, A. Nowakowska, \& Z. Przygodzki, Region i jego rozwój w warunkach globalizacji. Warszawa: CeDeWu Wydawnictwa Fachowe.

36. Skowroński, A. (2006). Zrównoważony rozwój perspektywą dalszego postępu cywilizacyjnego. Problemy Ekorozwoju, 1(2), 47-57.

37. Sobol, D. (2017). Innowacyjność jako determinanta współczesnego rozwoju regionu. Acta Universitatis Nicolai Copernici Ekonomia, 48(2), 73-87. http://dx.doi.org/10.12775/ AUNC_ECON.2017.005.

38. Strzelecki, Z. (2008). Polityka regionalna. In: Z. Strzelecki (Ed.), Gospodarka regionalna i lokalna. Warszawa: PWN.

39. Świadek, A., and Tomaszewski, M. (2012). Endogeniczny i egzogeniczny rozwój innowacyjności w regionalnych systemach przemysłowych Polski - studia przypadków. Zeszyty Naukowe Uniwersytetu Szczecińskiego. Ekonomiczne Problemy Usług, 91, 87-88.

40. Szewczuk, A. (2011). Filozofia i perspektywa zarządzania rozwojem lokalnym i regionalnym. In: A. Szewczuk, M. Kogut-Jaworska, \& M. Zioło, Rozwój lokalny i regionalny. Teoria i praktyka. Warszawa: C.H. Beck.

41. Szostak, E. (2015). Inteligentne specjalizacje w rozwoju regionu. Studia Ekonomiczne, 209, 209-217.

42. Trojak, M. (2013). Regionalne zróżnicowanie rozwoju ekonomicznego Polski. Kraków. Wydawnictwo Uniwersytetu Jagiellońskiego.

43. Tuziak, A. (2017). Innowacyjność i kapitał ludzki w rozwoju regionu. Nierówności Społeczne a Wzrost Gospodarczy, 52, 106-120. Doi: 10.15584/nsawg.2017.4.7. 
44. W kierunku innowacyjnej Polski: Proces przedsiębiorczego odkrywania i analiza potrzeb przedsiębiorstw w Polsce (2015). World Bank Group.

45. Wiktorska-Święcka, A., Klimowicz, M., and Michalewska-Pawlak, M. (2017). Innowacje we wspótzarzadzaniu rozwojem regionalnym. Praktyka instytucjonalna $w$ wybranych regionach $w$ Polsce. Warszawa-Wrocław: Oficyna Wydawnicza ASPRA. Uniwersytet Wrocławski. 